Nor is the Labour party, despite its egalitarian social philosophy, being squeamish about calling for a greater concentration on high performers when it comes to the distribution of funding for research. A director of one of Britain's leading pharmaceutical companies says that his biggest problem with a Labour government would be if it started "levelling downwards" in allocating research funds. But this seems unlikely, as the Labour party now espouses concentration and selectivity with, if anything, even greater fervour than the Conservatives.

"We must focus on the best," says Ian Gibson, dean of biological sciences at the University of East Anglia, who is standing as Labour candidate for the marginal seat of Norwich (North). Gibson, who raised the score of his department in the government's research assessment exercise from 3 in 1992 to 5 in 1996, and if elected will join a steadily growing band of scientifically-trained Members of Parliament, says that a commit- ment to good research is essential. "You may have to be really hard about it, and be prepared to say that the best is the best".

Perhaps wisely, the issue where attitudes to selectivity will have the greatest impact namely the future organization of universities - has been 'kicked into touch' as far as the election is concerned by the government's decision last year, endorsed by Labour, to pass it to an inquiry headed by the former civil servant Sir Ron Dearing.

\section{Opening and opportunities}

It will be less easy for Ingram, or whoever else is awarded the science portfolio, to avoid pressures on the science base to cut costs and increase cost-effectiveness. The easy political points have been made by expressions of outrage at the government's recently abandoned efforts to implement the wide-scale privatization of government research laboratories (see Nature 385, 473; 1997).

But pressures will remain to eliminate research in government-funded institutes that is considered insufficiently productive - a move that is likely to put a Labour government in conflict with the unions, as redundancies could well be involved.

Ironically, therefore, even those scientists who support the Labour party accept that they are unlikely to be substantially better off under a Labour government. But there is still optimism that the party may be able to fill perceived gaps in UK science policy - such as the lack of strong coordination between government departments, or a robust strategy to defend those on short-term contracts.

And even those who remain disappointed at the lack of manifesto commitments remain confident that there will be an opportunity to influence policy once the election is over. "All bets are off until then," says one active member of the support group Scientists for Labour. "After that, our hope is that, if we shout loud enough, they will listen."

\title{
Little change in the politics of science - but closer links with industry?
}

[LONDON] One of several areas in which the expected election of a Labour government in Britain is likely to have minimal impact on British science is the allocation of political responsibility for the science base.

Two years ago, the Conservative government shifted this responsibility from the Cabinet Office, symbolically close to the prime minister, to the Department of Trade and Industry (DT). The move produced howls of outrage at the apparent demotion of science in the political pecking-order (see Nature 376, 103; 1995).

Many scientists who support the Labour party would like to see the decision reversed, or indeed for science to be given its own government department, arguing that this is necessary to meet the party's promise to put science "at the heart of government thinking".

Robin Walters, for example, a researcher at the University of Sheffield and secretary of the 300 -strong group Scientists for Labour, says one of the group's priorities is to ensure that science is given full cabinet status.

A similar demand has been made by the lobby group Save British Science. There has been some response in political circles, notably from the Liberal Democrats, who are committed to moving the Office of Science and Technology (OST) back to the Cabinet Office.

But Labour has wavered. At times in the past, it has been in favour of a separate minister for science. This time, however, while criticizing the haste and lack of consultation about the

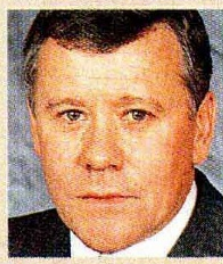
move to the DTI, it has no plans to change it According to Adam Ingram, Ingram: 'working shadow with industry? minister for science and technology, part of the reason is that, after four years of upheaval which started with the publication of the science white paper in 1993, the party has no desire to impose further disruption on the scientific community.

An equally powerful reason, however, lies in the fact that Labour is committed to forging even tighter links between the science base and the private sector than the Conservatives. This commitment is summed up in Ingram's words that a Labour government will work "with and on behalf of industry". From this perspective, placing OST within the DT makes sense.

As with Labour's broader policies, this strategy has met a mixed response. Many scientists fear that leaving the OST where it is risks increasing pressure on research councils to tailor their activities to an industry-led agenda.

But Ingram is unapologetic, arguing that "people should not sit in their ivory towers and be frightened of industry, because if industry does not work effectively there is no future for a strong science base in this country".

Where Labour does promise change is in the coordination of research policies across government departments. It is widely agreed that the reforms promised in the white paper have made relatively little impact in this area of activity.

In principle, such coordination is the responsibility of the head of the OST, who doubles as the chief scientific adviser to the government. In practice, the OST's relative lack of leverage over the research activities of high-spending departments has only been exacerbated by the move to DT.

Anne Campbell, Member of Parliament for Cambridge and an influential voice within the party, says: "I would like to see the chief scientific adviser's position strengthened, so that he really is a 'Mr Science' in government, with more authority over the other scientific advisers, and the ability to ensure that the government's overall strategy for science is better followed."

Ingram concurs, arguing that such an individual would, in practice, be in a better position to achieve such coordination than a cabinet minister because he or she would be able to use arguments about the need for high-quality science and science advice to avoid the "internecine warfare" between government ministers.

As a step in this direction, Labour has already promised to appoint a separate chief scientist at the DT, a post abolished by the Conservatives in the 1995 reshuffle, and now occupied in principle by the head of the OST, who doubles it with his role as adviser to the prime minister.

Further changes will have to await the outcome of what Ingram describes as a "period of quiet reflection" which the Labour party has promised will follow the election if it wins - and which some feel has provided an excuse for its reluctance to offer firm plans before the election.

Meanwhile Ingram says that there are no plans to replace Sir Robert May, the chief scientist, or Sir John Cadogan, director general of research councils. Both are civil servants and entitled to remain in their posts after the election.

D.D. 